\section{Environmental Best Practices}

\section{7-10 August 2006, Olszztyn, Poland}

The First International Environmental Best Practices Conference (EBP) will be held 7-10 August 2006 at the University of Warmia and Mazury in Olsztyn, Poland. The EBP conference is organized in collaboration with the Sam Houston University, Huntsville, Texas.

The objective of the conference is to bring together researchers from academic, governmental and industrial institutions to discuss new developments and results in the fields of environmental remediation, wastewater treatment, solid waste management, alternative energy sources and environmental stewardship. It is anticipated that attendees will develop a knowledge and understanding of a broad spectrum of environmental applications and solutions to the challenges facing the world today.

This conference is best suited for individuals working in the fields of Biology, Chemistry, Engineering, Government Regulation and Project Management.

The conference topics will include:

- Environmental Remediation (in situ and ex situ, bioavailability and genotoxicity of compounds, mycotoxins, monitoring of pollutants, modelling contamination)
- Wastewater Treatment (centralized and decentralized systems, sewage sludge processing and disposal)

- Solid Waste Management (strategies, resource recovery and reuse, landfilling, pretreatment)

- Alternative Energy Sources (fuel cell, biofuels, organic solid waste, solar power, liquefied natural and petroleum gas, wind, tidal, geothermal, hydroelectric)

- Environmental Stewardship (agriculture, ecotourism, native flora and fauna, invasive species, water quality and environmental indicators, impact assessment of engineering and biotechnological undertakings)

The social program will include a reception at Olsztyn Castle, a banquet at the lake shore, a postconference tour to Gdansk and surrounding anti-flood installations. For accompanying persons, there are various tours available, including visits to historical places, museums and leisure centers.

See Mark Your Calendar on page 38 for contact information.

www.uwm.edu.pl/wosir/EBP

and Biological Applications of Time-Resolved Spectroscopy (Kobe, 18-19 August), Tsukuba Satellite Symposium on Single Molecule and Tip-Enhanced Raman Scattering (Tsukuba, 17-19 August), International Symposium on Surface-Enhanced Raman Scattering and Spectroscopy (Nishinomiya, 28-29 2006 in the city of Yokohama, Japan, and will be chaired by University of Tokyo Professor Hiro-o Hamaguchi. Seventeen subjects or groups of topics will cover all aspects of basic and applied Raman spectroscopy, including theory; resonance and time-resolved Raman spectroscopy and ultrafast phenomena; vibrational analysis and molecular structure; thin layers, surfaces, and interfaces; and applications to material science, technology, biology, and medicine.

Six satellite meetings will focus on specific subjects related to Raman spectroscopy. These include an International Workshop on X-Ray Raman and Related Phenomena (Okazaki, 17-20 August), Protein Dynamics
August), New Horizon of Medical Applications of Spectroscopy (Tokyo, 26-27 August), and Ultrafast Time-Resolved and TimeDomain Vibrational Spectroscopy (Wako, 18-19 August).

About 500 people from more than 25 countries are expected to attend this ICORS meeting-a grand forum for those interested in new Raman spectroscopy.

See Mark Your Calendar on page 39 for contact information.

\section{www.pac.ne.jp/icors2006}

